\title{
Poverty Alleviation: An Economic Practice Study of Islamic Culture
}

\author{
RENNY OKTAFIA \\ Sekolah Pascasarjana, \\ Universitas Airlangga \\ Surabaya, East Java, Indonesia \\ Email : \\ renny.oktafia@umsida.ac.id
}

\author{
MUSLICH ANSHORI \\ Sekolah Pascasarjana, \\ Universitas Airlangga \\ Surabaya, East Java, Indonesia \\ Email : slich@feb.unair.ac.id
}

\author{
IMRON MAWARDI \\ Sekolah Pascasarjana, \\ Universitas Airlangga \\ Surabaya, East Java, Indonesia \\ Email : \\ ronmawardi@feb.unair.ac.id
}

\begin{abstract}
Indonesia's wealth can be seen from the natural resources owned and contained in the earth, sea and in the air of the country. In addition, there is another great wealth; cultural richness. Similarly, the culture contained in Indonesia comes in a variety of forms, ranging from and including dance, handicrafts, art music to economic activities. In conducting its economic activities, it turns out that there are many forms of ordinance in running it. This form of cultural-based economic activity has then shifted into a capitalist system with the entry of Dutch colonialists. This research study used a qualitative method, with the approach of a research literature study using journals, books and other scientific works related to the research focus. The results show that cultural-based economic activities in Indonesia are an economic form that is in accordance with the teachings of Islam, because it implements the rules to get the corresponding results. Therefore, it needs to be raised and re-applied massively in society. It is expected that the principle of mutual assistance in cultural-based economic activities can reduce the gap between the economic strata. In the end, it is expected that we can reduce poverty in the community by cooperating with other owned resources.
\end{abstract}

Keywords: Islamic Economic, Culture, Cooperation, Poverty

\section{INTRODUCTION}

Poverty is one of the main problems faced by developing countries. Similarly Indonesia is a developing country that always places poverty as a priority goal to be addressed immediately, through important developmental implementation agendas.
This is based on data from 2016, which shows that the poverty rate in Indonesia is still high, reaching approximately 28 million people or more than $10 \%$ of the total population of Indonesia (www.bps.go.id, 2017). With the natural resources owned by Indonesia, this potential can be used to improve the economy of the community.

In the management of natural resource wealth, it is necessary to note the method used in its utilisation so that it can be kept sustainable. In addition, the important thing is also about the mechanism of economic activity in the utilisation and distribution of natural resources. Thus, the economic activities undertaken can improve the economy of all Indonesian people. In applying these economic activities, they should be based on Islamic values. Islam is a religion that is upheld by the majority of Indonesia's population. In addition, Islamic economics implement a fairer system for those who run it.

In Indonesia itself, there are various cultures that characterise the tribes spread throughout the archipelago. This is where the culture has become the wealth of the Indonesian nation, not only in the form of language and art activities. Economic activity is carried out in the fulfilment of economic needs. When learning more deeply, it appears that culturalbased economic activities are very much in line with Islamic economic practices. This phenomenon has been expressed through research conducted by several researchers. 
Researchers who describe the economic activities carried out in a particular culture include Yulianti (2010) in their study entitled "Islamic Economics and Local Wisdom". Their research suggests that in Indonesia, there has been a lot of local wisdom that has implemented Islamic values. One of them that has been practiced by the Tengger tribal people is managing agricultural land which has applied a profit sharing system as taught in Islamic economics. In the Tengger tribal community, this profit sharing has been used to share the results of the harvest from landowners and smallholders during the harvest season. In sharing the results, the tiller farmers can get between $50 \%$ and $75 \%$ of the total harvest. The division of the results is based on the agreement that has been reached at the beginning of their cooperation.

\section{PURPOSE}

In fostering economic resilience, many efforts have been made to improve the stability of the economy in Indonesia. One effort that can be realised is by adopting local wisdom in managing the economic resources available in nature. In addition, local wisdom is used as a regulatory mechanism in economic activities. Therefore, this study aims to explore and lift the culture contained in the local wisdom owned by indigenous tribes in Indonesia.

By knowing more about the local wisdom owned by the Indonesian people, it can be used to improve the economic order. This is where economic practice can refer to existing local wisdom. Local wisdom is very concerned about the balance between humans, humans with nature, and humans with the creator. The teachings possessed by local wisdom are in accordance with the teachings and values of Islam.

\section{METHOD}

The research method used in this research study was qualitative. This method was used because it aims to obtain data in the form of a series of written words, so that the data obtained can be described in detail, based on observations obtained during the study (Azmar, 2001).

The research approach used was a literature research study, by collecting and processing the literature data. After the library data was collected, the data libraries were read to ensure that they were intact and thorough. By reading the literature data, the researcher recorded things that have become the core of the reviewed literature data. Furthermore, the latter processes the results of the accumulated records. This literature research does not require direct observation in the field (Mestika, 2004).

\section{RESULT AND DISCUSSION}

\section{A. Local Culture}

Local culture can be referred to as a system consisting of elements that show the peculiarities of a particular tribe. There are seven elements that exist in a culture: social system, livelihood system, knowledge system, religion, equipment life and technology, art and language (Setiyawan, 2012).

In Islam, the term adat is referred to as urf, which is defined as a legal system within Islam which contains habits that are propagated through mechanisms to regulate the prevailing legal order, so that customary roles can maintain the social and economic structures within the community (Moshood, 2013).

B. The Linkage of Local Cultures with Poverty Alleviation

Some of the studies that highlight local cultural relationships with poverty include:

1. (Saharuddin, 2009), who conducted a research called the "Empowerment of Poor Based Local Wisdom". They explained that local wisdom can serve as a driver in poverty alleviation. Local wisdom is gained through the interaction of the community with its environment, so it can be used to improve social problems related to life in the community. Furthermore, it can be explained in the form of the "gotong royong" culture that has been owned by the Indonesian people in the past. There are teachings used to help each other in the surrounding community. This could be a mutual aid in relation to economic activity, as applied by the Tengger people who help fellow citizens in need of an economic income. The applied form is through cooperation between the landowner and the farmer with the harvest sharing system. 
Thus, people who are unemployed and have insufficient capital to start a business can earn an income through the existing system of cooperation in the indigenous culture.

2. (Chaiphar, 2013) Local Wisdom in the Environmental Management of a Community: Analysis of Local Knowledge in Tha Pong Village, Thailand" says that sustainable management and the protection of natural resources can be done through an approach utilising local wisdom. The surrounding community can utilise natural resources as materials to produce handicrafts in accordance with the characteristics of the region, so as to their increase revenue.

3. (Primyastanto, 2013) "Fisheries Resources Management by Empowering the Local Wisdom in Madura Straits" says that local wisdom can be used as a rule in managing fishery and marine resources. This is done to prevent the destruction of marine resources, which is a result of human nature that always manifests unlimited desire. Thus, everything generated from marine resources can be felt equally by society to improve its economy.

4. Another research conducted by (Hermansyah, 2013) had the title "Local Wisdom as a Model of Shari'ah Economic Approach". In this study, it is explained that local wisdom is spread all over Indonesia, which can be extracted and preserved in the framework of natural wealth management. Some areas have local wisdom actively used in the utilisation of this nature, including: - Dayak Kenyah tribe, East Kalimantan, has a custom called tana 'ulen which governs the management of forest areas in accordance with customary rules. - In Aceh, there is local wisdom called mukim, which means that local institutions can be used to empower the local economy.

5. (Hakim, 2014), in a journal entitled "Local Wisdom In Islamic Economics (Study on the Application of Al-Urfs as a Basis of Adoption)" explains that economic activity must be in line and adhere to the source of Islamic economic law. One source of Islamic law is urf, which can also be interpreted as local wisdom so that conducting economic activities is based on wise behaviour that is good for the community. If conducting economic activities based on local wisdom, there will be no imbalances that cause poverty for some of the communities. This condition will instil a feeling that carrying out economic activities should be useful not only for yourself, but also bring benefits to others. Then in the end, there will be an equitable distribution of the people's economic income, which can lift the poor in to a position for the better.

6. (Kusmanto, 2014), in a study entitled "Development of Population-Based Islamic Economics in Rural Areas", said that the village community strongly upholds local wisdom, where the local wisdom underlies the applied economic system. Indirectly, the economic system that refers to local culture is the same system as the Islamic economic system. Therefore, the Islamic economic system in the village has the potential to be developed, because the majority of villagers embrace Islam. To maximise the potential, it is necessary for there to be the participation of all parties in providing understanding to the community. With the increasing understanding of indigenous peoples around the economic activities of Islam based on the principles of justice, it will be beneficial for the reduction of poverty of the community.

7. (Suyanto, 2014), conducted a study entitled "Analysis on Local Wisdom-Based Green Community Participation Supporting Program at The Green City Purwokerto Indonesia (A Case Study of Household Waste Management) which states that community empowerment in household waste management can be done with a local wisdom approach which has been done several years ago with community participation to keep the environment green.

8. (Lisdiyono, 2015), stated in a study entitled "The Economic Value of Natural Resources and The Principle of Local Wisdom as Environmental Protection Efforts in Indonesia", that local wisdom can be used as a management system in protecting and preserving the environment. Environmental sustainability will generate 
economic benefits for the surrounding population. Therefore, the utilisation of natural resources in accordance with local wisdom will be able to provide maximise benefits for the welfare and quality of life of the community.

The results of the above research, states that by maintaining the existing culture or local wisdom, it can be used as a tool or approach in maintaining order and values in various aspects of life. This can then have an impact on the increase in economic value obtained by the community, which in turn can reduce the level of poverty. Based on the translation of the study, the culture and local wisdom is in accordance with the values contained in Islamic teachings.

\section{CONCLUSION}

Based on the above description, it can be concluded that the economic system should be tied in with local wisdom, as well as maintaining the Islamic economic system. This is due to the longstanding economic activities carried out by indigenous peoples in Indonesia, as part of the Islamic economic system that has value requirements for the actors. This Islamic economic activity, when applied thoroughly, can reduce the poverty that occurs today. Further research can explore the economic activities that are still stored in the local wisdom of various tribes in Indonesia which has not been fully analysed.

\section{ACKNOWLEDGMENT}

- Thanks to the Rector of Universitas Airlangga.

- Thank you to the Director of Sekolah Pascasarjana of Universitas Airlangga.

\section{REFERENCES}

Azmar, S. (2001). Metode Penelitian. Yogyakarta: Pustaka Pelajar.

Chaiphar, W. (2013). Local Wisdom in the Environmental Management of a Community: Analysis of Local Knowledge in Tha Pong Village, Thailand. Journal of Sustainable Development, Vol. 6(No. 8).

Hakim, A. (2014). KEARIFAN LOKAL DALAM EKONOMI ISLAM (Studi Atas Aplikasi al-Urf Sebagai Dasar Adopsi) Abdul Hakim (Fakultas
Syarieeah dan Ekonomi Islam UIN Sunan Ampel Surabaya), 8, 65-81.

Hermansyah. (2013). Kearifan Lokal Sebagai Model Pendekatan Ekonomi Syari'ah. Istinbath, 12(1), 167-204.

Kusmanto, T. Y. (2014). PENGEMBANGAN EKONOMI ISLAM BERBASIS KEPENDUDUKAN DI PERDESAAN. Jurnal Ilmu Dakwah, 34(2), 219235.

Lisdiyono, E. (2015). THE ECONOMIC VALUE OF NATURAL RESOURCES AND THE PRINCIPLE OF LOCAL WISDOM AS ENVIRONMENTAL PROTECTION EFFORTS IN INDONESIA. International Journal of Business, Economics and Law, Vol.7(Issue 4).

Mestika, Z. (2004). Metode Penelitian Kepustakaan. Jakarta: Yayasan Bogor Indonesia.

Moshood, T. (2013). 'URF/ 'ADAH (CUSTOM): AN ANCILLARY MECHANISM IN SHARI'AH. Ilorin Journal of Religious Studies (IJOURELS), 3(2), 133-148.

Primyastanto, M. (2013). Fisheries Resources Management by Empowering the Local Wisdom in Madura Straits. Research on Humanities and Social Sciences, Vol.3(No. 6).

Saharuddin. (2009). Pemberdayaan Masyarakat Miskin Berbasis Kearifan Lokal. Sodality, 3(1), 17-44.

Setiyawan, A. (2012). Budaya Lokal Dalam Perspektif Agama: Legitimasi Hukum Adat ('Urf) Dalam Islam. Esensia, XIII(2).

Suyanto, E. (2014). ANALYSIS ON LOCAL WISDOMBASED GREEN COMMUNITY PARTICIPATION SUPPORTING THE DEVELOPMENTAL PROGRAM AT THE GREEN CITYPURWOKERTO INDONESIA (A CASE STUDY OF HOUSEHOLD WASTE MANAGEMENT). International Journal of Research In Earth \& Environmental Sciences, Vol. 2(No.5).

www.bps.go.id. (2017). No Title.

Yulianti, R. T. (2010). Ekonomi islam dan kearifan lokal. Millah, Edisi Khus, 99-115. 